\title{
Efek Hujan Asam terhadap Pertum buhan Tanaman
}

\author{
Mimatun Nasihah ${ }^{1}$ \\ Email: $\underline{\text { m.nasihah@yahoo.co.id }}$ \\ 1) Dosen Program Studi Ilmu Lingkungan Universitas Islam Lamongan
}

\begin{abstract}
Abstrak
Pencemaran Udara adalah peristiwa masuknya, atau tercampurnya, polutan (unsur-unsur berbahaya) ke dalam lapisan udara (atmosfer) yang dapat mengakibatkan menurunnya kualitas udara (lingkungan). (Hogan, 1973). Hujan asam diartikan sebagai berbagai macam hujan dengan $\mathrm{pH}$ di bawah 5,6. Hujan secara alami bersifat asam ( $\mathrm{pH}$ sedikit di bawah 6) karena karbondioksida $\left(\mathrm{CO}_{2}\right)$ di udara yang larut dengan air hujan memiliki bentuk sebagai asam lemah. Tanaman dipengaruhi oleh hujan asam dalam berbagai macam cara. Lapisan lilin pada daun rusak sehingga nutrisi menghilang sehingga tanaman tidak tahan terhadap keadaan dingin, jamur dan serangga. Pertumbuhan akar menjadi lambat sehingga lebih sedikit nutrisi yang bisa diambil, dan mineral-mineral penting menjadi hilang. Metode penelitian ini eksperimen yakni Penelitian ini menggunakan metode eksperimental yaitu suatu penelitian yang dengan sengaja peneliti melakukan manipulasi terhadap satu atau lebih variabel dengan suatu cara tertentu sehingga berpengaruh pada satu atau lebih variabel lain yang diukur. Hasil penelitian ini menunjukan bahwa terdapat pengaruh hujan asam terhadap pertumbuhan tanaman. Semakin banyak hujan asam/semakin rendah $\mathrm{pH}$ air maka pertumbuhan tanaman semakin tidak normal, tidak hanya pertumbuhan yang tidak normal tetapi banyak tanaman yang tidak bisa tumbuh.
\end{abstract}

Kata Kunci : Pencemaran Udara, Hujan Asam, Pertumbuhan Tanaman.

\section{PENDAHULUAN}

Pencemaran udara adalah peristiwa masuknya, atau tercampurnya, polutan (unsur-unsur berbahaya) ke dalam lapisan udara (atmosfer) yang dapat mengakibatkan menurunnya kualitas udara (lingkungan). Pencemaran dapat terjadi dimanamana. Bila pencemaran tersebut terjadi di dalam rumah, di ruang-ruang sekolah ataupun di ruangruang perkantoran maka disebut sebagai pencemaran dalam ruang (indoor pollution). Sedangkan bila pencemarannya terjadi di lingkungan rumah, perkotaan, bahkan regional maka disebut sebagai pencemaran di luar ruang (outdoor pollution) (Hogan, 1973).

Umumnya, polutan yang mencemari udara berupa gas dan asap. Gas dan asap tersebut berasal dari hasil proses pembakaran

bahan bakar yang tidak sempurna, yang dihasilkan oleh mesin-mesin pabrik, pembangkit listrik dan kendaraan bermotor. Selain itu, gas dan asap tersebut merupakan hasil oksidasi dari berbagai unsur penyusun bahan bakar, yaitu: $\mathrm{CO}_{2}$ (karbondioksida), $\mathrm{CO}$ (karbonmonoksida), $\mathrm{SO}_{\mathrm{x}}$ (belerang oksida) dan $\mathrm{NO}_{\mathrm{x}}$ (nitrogen oksida), CFC dan asap rokok.

Pengertian Hujan asam diartikan sebagai berbagai macam hujan dengan $\mathrm{pH}$ di bawah 5,6.
Hujan secara alami bersifat asam $(\mathrm{pH}$ sedikit di bawah 6) karena karbondioksida $\left(\mathrm{CO}_{2}\right)$ di udara yang larut dengan air hujan memiliki bentuk sebagai asam lemah. Jenis asam dalam hujan ini sangat bermanfaat karena membantu melarutkan mineral dalam tanah yang dibutuhkan oleh tumbuhan dan binatang. Hujan asam disebabkan oleh belerang (sulfur) yang merupakan pengotor dalam bahan bakar fosil serta nitrogen di udara yang bereaksi dengan oksigen membentuk sulfur dioksida dan nitrogen oksida. Zat-zat ini berdifusi ke atmosfer dan bereaksi dengan air untuk membentuk asam sulfat dan asam nitrat yang mudah larut sehingga jatuh bersama air hujan. Air hujan yang asam tersebut akan meningkatkan kadar keasaman tanah dan air permukaan yang terbukti berbahaya bagi kehidupan ikan dan tanaman.

Sumber hujan asam secara alami dapat terjadi akibat semburan dari gunung berapi dan dari proses biologis di tanah, rawa, dan laut. Akan tetapi, mayoritas hujan asam disebabkan oleh aktivitas manusia seperti industri, pembangkit tenaga listrik, kendaraan bermotor dan pabrik pengolahan pertanian (terutama amonia). Gas-gas yang dihasilkan oleh proses ini dapat terbawa angin hingga ratusan kilometer di atmosfer sebelum berubah menjadi asam dan terdeposit ke tanah. 
Tanaman dipengaruhi oleh hujan asam dalam berbagai macam cara. Lapisan lilin pada daun rusak sehingga nutrisi menghilang sehingga tanaman tidak tahan terhadap keadaan dingin, jamur dan serangga. Pertumbuhan akar menjadi lambat sehingga lebih sedikit nutrisi yang bisa diambil, dan mineral-mineral penting menjadi hilang.

Setiap organisme, baik hewan maupun tumbuhan mempunyai kemampuan beradaptasi terhadap lingkungannya. Sebagai contoh, tanaman mempunyai kemampuan hidup yang baik jika tumbuh di tanah dengan $\mathrm{pH}$ antara 6 sampai 7. Air hujan normal mempunyai tingkat $\mathrm{pH}$ antara 5,8 sampai 6. Sementara $\mathrm{pH}$ hujan asam berada di bawah 5,8. Hal tersebut akan mempengaruhi pertumbuhan tanaman. Apakah hujan asam berpengaruh terhadap pertumbuhan tanaman? Bagaimanakah pengaruh hujan asam terhadap pertumbuhan tanaman?

\section{RUMUSAN MASALAH}

a. Bagaimanakah proses terjadinya hujan asam?

b. Apa saja penyebab terjadinya hujan asam ?

c. Bagaimanakah pengaruh hujan asam terhadap pertumbuhan tanaman?

\section{TUJUAN PENELITIAN}

a. Untuk mengetahui bagaimana proses terjadinya hujan asam

b. Untuk mengetahui penyebab terjadinya hujan asam

c. Untuk mengetahui pengaruh hujan asam terhadap pertumbuhan tanaman.

\section{METODE PENELITIAN}

Penelitian ini menggunakan metode eksperimental yaitu suatu penelitian yang dengan sengaja peneliti melakukan manipulasi terhadap satu atau lebih variabel dengan suatu cara tertentu sehingga berpengaruh pada satu atau lebih variabel lain yang diukur (Arboleda 1981: 27).

\section{VARIABEL PENELITIAN}

a. Variabel Kontrol: Jenis Tanaman, Jenis kapas, banyaknya kapas, waktu penyiraman, jumlah air yang disiramkan

b. Variabel Bebas : Hujan asa

c. Variabel Terikat: Pertumbuhan Tanaman

\section{HASIL PENELITIAN}

Tabel 1 Hasil pengamatan pertumbuhan tanaman pada hari ke 2 .

\begin{tabular}{|c|c|c|c|}
\hline \multirow[b]{2}{*}{ No } & \multirow[b]{2}{*}{ Perlakuan } & \multicolumn{2}{|c|}{$\begin{array}{l}\text { Pertumbuhan Kecambah } \\
\text { pada hari ke dua (48 jam) }\end{array}$} \\
\hline & & $\begin{array}{c}\text { Rata2 } \\
\text { Jumlah } \\
\text { kecambah }\end{array}$ & $\begin{array}{c}\text { Rata2 } \\
\text { Panjang } \\
\text { kecambah }\end{array}$ \\
\hline 1 & $\mathrm{pH} 6$ & 14 & $13.8 \mathrm{~cm}$ \\
\hline 2 & $\mathrm{pH} 5$ & 11 & $8,2 \mathrm{~cm}$ \\
\hline 3 & $\mathrm{pH} 4$ & 6 & $4.6 \mathrm{~cm}$ \\
\hline 4 & $\mathrm{pH} 3$ & 3 & $2 \mathrm{~cm}$ \\
\hline
\end{tabular}

\section{PEMBAHASAN}

Perlakuan yang berbeda pada penyiraman tanaman, maka pertumbuhan tanaman pun berbeda. Tanaman yang disiram dengan menggunakan air dengan $\mathrm{pH}$ normal (6), mampu berkecambah semua dan tumbuh dengan normal, sementara tanaman yang disiram dengan air yang mengandung asam cuka tumbuh tidak bisa normal, agak kerdil dan tidak bisa tumbuh optimal. Semakin turun pHnya maka jumlah biji yang berkecambah semakin sedikit. Adapun yang berkecambah, tingkat pertumbuhannya sangat kerdil.

Perbedaan terletak pada pertumbuhan tanaman. Untuk tanaman yang disiram dengan menggunakan air dengan $\mathrm{pH}$ netral $(\mathrm{pH}$ 6) pertumbuhannya cenderung normal, tidak ada hambatan, dan tumbuh dengan baik. Berbeda dengan tanaman yang disiram dengan menggunakan air yang mengandung asam cuka, pertumbuhannya tidak bisa optimal, tanaman cenderung tumbuh dengan kerdil dan tidak sehat.

Yang membedakan pertumbuhan pada dua jenis perlakuan tersebut adalah kandungan asam pada tanaman yang disiramkan. Air yang mengandung asam cuka (atau dikenal dengan istilah hujan asam) mengandung belerang (sulfur) yang merupakan pengotor dalam bahan bakar fosil serta nitrogen di udara yang bereaksi dengan oksigen membentuk sulfur dioksida dan nitrogen oksida. Air hujan yang asam tersebut akan meningkatkan kadar keasaman tanah dan air permukaan yang terbukti berbahaya bagi kehidupan tanaman. Adapun bahaya tersebut antara lain: Lapisan lilin pada daun rusak sehingga nutrisi menghilang yang akhirnya tanaman tidak tahan terhadap keadaan dingin, jamur dan serangga. Pertumbuhan akar menjadi lambat sehingga lebih sedikit nutrisi yang bisa diambil, dan mineral-mineral penting menjadi hilang. 
Hujan asam diartikan sebagai segala macam hujan dengan $\mathrm{pH}$ di bawah 5,6. Hujan secara alami bersifat asam ( $\mathrm{pH}$ sedikit di bawah 6) karena karbondioksida $\left(\mathrm{CO}_{2}\right)$ di udara yang larut dengan air hujan memiliki bentuk sebagai asam lemah. Hujan asam disebabkan oleh belerang (sulfur) yang merupakan pengotor dalam bahan bakar fosil serta nitrogen di udara yang bereaksi dengan oksigen membentuk sulfur dioksida dan nitrogen oksida. Zat-zat ini berdifusi ke atmosfer dan bereaksi dengan air untuk membentuk asam sulfat dan asam nitrat yang mudah larut sehingga jatuh bersama air hujan.

Dampak Hujan asam adalah Air hujan yang asam tersebut akan meningkatkan kadar keasaman tanah dan air permukaan yang terbukti berbahaya bagi kehidupan ikan dan tanaman. Bagi ikan: $\mathrm{pH}$ di bawah 4,5 tidak memungkinkan bagi ikan untuk hidup, asam di dalam air akan menghambat produksi enzim dari larva ikan trout untuk keluar dari telurnya. Asam juga mengikat logam beracun seperi alumunium di danau. Alumunium akan menyebabkan beberapa ikan mengeluarkan lendir berlebihan di sekitar insangnya sehingga ikan sulit bernafas. Bagi tumbuhan: Tanaman dipengaruhi oleh hujan asam dalam berbagai macam cara. Lapisan lilin pada daun rusak sehingga nutrisi menghilang sehingga tanaman tidak tahan terhadap keadaan dingin, jamur dan serangga. Pertumbuhan akar menjadi lambat sehingga lebih sedikit nutrisi yang bisa diambil, dan mineral-mineral penting menjadi hilang.

Faktor-faktor yang mempengaruhi pencemaran udara antara lain gas dan asap yang berasal dari hasil proses pembakaran bahan bakar yang tidak sempurna, atau yang dihasilkan oleh mesin-mesin pabrik, pembangkit listrik dan kendaraan bermotor, atau berasal dari hasil oksidasi dari berbagai unsur penyusun bahan bakar yaitu $\mathrm{CO}_{2}, \mathrm{CO}, \mathrm{SOx}, \mathrm{NOx}$ atau $\mathrm{CFC}$ dll.

- Karbondioksida. Berasal dari pabrik, mesin, mobil, kapal, pesawat terbang. Dapat menimbulkan efek rumah kaca.

- Karbon monoksida. Berasal dari menghidupkan mesin mobil dalam garasi tertutup. Bersifat racun yang dapat menyebabkan kematian.

- Chloro Fluoro Carbon. Digunakan sebagai gas pengembang, untuk AC, lemari es. Dapat menipiskan lapisan ozon.
- Nitrogen Oksida. Berasal dari alat transportasi terutama laut. Nitrogen oksida di udara yang dihirup oleh manusia menyebabkan kerusakan paru-paru.

- Belerang Oksida. Berasal dari pembakaran minyak dan batu bara. Dapat bereaksi dengan gas nitrogen oksida dan air hujan yang menyebabkan terjadinya hujan asam.

Usaha untuk mencegah dan menanggulangi terjadinya hujan asam antara lain: Di Amerika Serikat, banyak pembangkit tenaga listrik tenaga batu bara menggunakan Flue gas desulfurization (FGD) untuk menghilangkan gas yang mengandung belerang dari cerobong mereka. Sebagai contoh FGD adalah wet scrubber yang umum digunakan di Amerika Serikat dan negara-negara lainnya. Wet scrubber pada dasarnya adalah tower yang dilengkapi dengan kipas yang mengambil gas asap dari cerobong ke tower tersebut.Kapur atau batu kapur dalam bentuk bubur juga diinjeksikan ke ke dalam tower sehingga bercampur dengan gas cerobong serta bereaksi dengan sulfur dioksida yang ada, Kalsium karbonat dalam batu kapur menghasilkan kalsium sulfat ber $\mathrm{pH}$ netral yang secara fisik dapat dikeluarkan dari scrubber. Oleh karena itu, scrubber mengubah polusi menjadi sulfat industri. Adapun usaha untuk mencegah yang lainnya adalah, karena hujan asam itu mayoritas disebabkan oleh aktivitas manusia seperti industri, pembangkit tenaga listrik, kendaraan bermotor dan pabrik pengolahan pertanian, maka usaha yang bisa dilakukan adalah dengan meminimalisir penggunaan bahan-bahan atau meminimalisir aktivitas yang bisa menyebabkan terjadinya hujan asam tersebut. Di Indonesia selama ini baru bisa mencegah terjadinya hujan asam yakni dengan melakukan penghematan energi

\section{KESIMPULAN}

Kesimpulan dari hasil pengamatan adalah hujan asam berpengaruh negatif terhadap perkecambahan biji kacang hijau. Hujan asam mempengaruhi tingkat pertumbuhannya yang tidak bisa optimal, kecambah kacang hijau tidak bisa tumbuh dengan normal, pertumbuhan cenderung terhambat, bahkan pada $\mathrm{pH}$ dibawah 3 kacang hijau tidak bisa berkecambah. Selain itu hujan asam juga merusak lapisan lilin pada daun yang merupakan pelindung daun sehingga daun lebih mudah terserang jamur maupun hama, pertumbuhan akar juga terhambat sehingga nutrisi dari tanah yang diambil juga hanya sedikit. 
Adapun beberapa saran yang diberikan oleh penulis yaitu antara lain,

a. Perlu dilakukan penelitian tindak lanjut tentang dampak hujan asam terhadap pertumbuhan makhluk hidup yang lain.

b. Hasil penelitian ini supaya bisa dijadikan sebagai bahan rekomendasi kepada pemerintah untuk membuat kebijakan terkait dengan upaya pengurangan pencemaran lingkungan.

\section{DAFTAR PUSTAKA}

Afandi, 2009. Dampak Polusi terhadap Kesehatan Manusia. Diakses melalui http://dahlanforum.wordpress.com/2009/07/ 07/dampak-polusi-terhadap-kesehatanmanusia/. pada tanggal 20 Februari 2017.

Cahyadi, D. 2010. Polusi atau Pencemaran Lingkungan. Diakses melalui http://adiwiyatasmansa.blogspot.com/2010/0 6/polusi-atau-pencemaran-lingkungan.html. pada tanggal 20 Februari 1017.

Kantor Menteri Negara Lingkungan Hidup, 1997. Agenda 21 Indonesia, Strategi Nasional untuk Pembangunan Berkelanjutan, Kantor Menteri Negara Lingkungan Hidup, Jakarta.

Keraf, S. 2004. Bencana dan Krisis Lingkungan Global. Materi TOT PKLH Dikdasmen di Sawangan Bogor

Koestoer, Y. 1995. Kimia dan Ekotoksikologi Pencemaran. Jakarta: Universitas Indonesia Press.

\section{Novi, 2011 Materi Pencemaran Lingkungan. Diakses melalui http://hend- learning.blogspot.com/2009/04/pencemaran- lingkungan.html. pada tanggal 20 Februari 2017.}

Peraturan Menteri Negara Lingkungan Hidup. Nomer 13 Tahun 2010. Tentang Upaya Pengelolahan Lingkungan Hidup. Jakarta.

Soemarwoto, O. 1997. Ekologi, Lingkungan Hidup dan Pembangunan. Jakarta: Penerbit Jambatan

Supriyadi, M. 2010. Pencemaran Lingkungan. Diakses melalui http://mamansupriadi.wordpress.com/2010 /04/. pada tanggal 22 Februari 2017.

Surakusima, Wahyu. 2010 "Konsep Pendidikan Lingkungan Hidup" http/www. erizco.wordpress.com. diakses pada tanggal 20 Februari 2017.

Wardhana, W.A. 1995. Dampak Pencemaran Lingkungan. Penerbit Andi Offset. Yogyakarta

Widiantoro, R. 2008. Limbah Industri Potensi Penyebab Pencemaran Air. Diakses melalui http://annauzuma.wordpress.com/ipa-12/peran-manusia-dalam-pengelolaanlingkungan/. pada tanggal 20 Februari 2017. 